(2) infection, and (3) degeneration-diet seems to have the least to do with the decay of the teeth. Has anyone ever seen satisfactory results from wholemeal bread, " jaw drill," vegetable diet, or the score of other diet treatments? Dentists seldom look beyond their patients' teeth, so their theory that decay is due to neglect of the teeth is not worth much. Moreover, decay still goes on when the dentist has complete control.

I think it not unlikely that the improvement in dentistry has something to do with the increase of dental decay. When loss of teeth meant loss of health and life natural selection kept the teeth strong. Even a generation or two ago a woman with defective teeth had less chance of marriage, and so sexual selection also tended to preserve a disease-resisting type. But now the dentist has altered all this, and a complete set of false teeth is no detriment to a young woman; American women are even said to pride themselves on their gold stopping. I think you find the worst cases of infant dental caries in the offspring of mothers with decaying teeth, suggesting that decay may be due to direct infection. Infection acting upon degenerate teeth seems to me the only feasible theory, but the question can only be answered by the careful collection of facts.

I am, Sir, yours faithfully,

Silverton, Devon, Oct. 19th, 1908.

O. Clayton Jones.

\section{CARDIAC MOTION AS REVEALED BY THE VIVISECTION OF DISEASE.}

\section{To the Editor of The Lancet.}

SIR,- In the report of the proceedings of the Asculapian Society which appeared in THE LANCET of Oct. 17th, the energetic secretary of the society whose succinct and accurate reports you regularly publish, slightly misunderstood two points in this instance, which, with your permission, I shall correct without delay, as the matters in question may be discussed again. In the first place, the sarcomatous invasion of the right auricle and ventricle very greatly restricted the contractility of those chambers, but as there was some uninvolved muscular tissue in both there may have been a very limited movement of both. In the next place the patient I showed was the case of thoracostomy for cardiac pain, an account of which you published in THE LANCET of July 4 th, 1908, and while it was the first case operated upon for this cause it was not by any means the first case of thoracostomy for heart disease.

I am, Sir, yours faithfully,

ALEXANDER MORISON, M.D. Edin.

Upper Berkeley-street, Portman-square, W., Oct. 19th, 1908.

\section{A POINT UNDER THE WORKMEN'S COM- PENSATION ACT, 1906.}

To the Editor of THE LANCET.

SIR, - The Workmen's Compensation Act (1906) has laid a very serious trap into which our patients may unwittingly fall. A patient of mine, a chronic invalid, quite helpless, sent for a male attendant from an institution to act as stopgap during the illness of a permanent attendant. When the substitute had been in the house three days he ruptured some fibres of his diaphragm and has been invalided for over six months. The institution has no insurance for its men and the patient's insurance does not cover such a claim. Heavy claims are being made against my patient and he will probably have to disprove his liability in court, as the Act is so indefinite and so badly drafted as regards this point. It behoves medical men in the interests of their patients to ascertain what nursing "institutions" are insured and to recommend those only, and it would be to every one's interest that such concerns should announce in their advertisements the fact that they do insure their nurses.

I am, Sir, yours faithfully,

Oct. 16th. 1908 CAUTTOUS

The Water-Supply of St. Just (CorNwall). -The St. Just Urban District Council, by its neglect to provide the town with an adequate water-supply, has exhausted the parience of the Cornwall County Council, which has complained to the Local Government Board and asked for an inquiry.

\section{THE SANITARY DEFENCE OF THE HEDJAZ RAILWAY.}

(By the British Delegate on the Constantinople BOARD OF HEALTH.)

(Illustrated with Reproduotions of Photographs taken by the Author.)

III. ${ }^{3}$ - MEDAINI-SALIH.

ABOUT two hours after leaving Tebuk our train passed through another rocky valley, known as the Zahr-el-Akhdar, and shortly after reached the "station" of Akhdar. There is no village here, nothing but the fortress-like station building. About two kilometres further on we stopped again, at the junction of two valleys; there is here a large reservoir with pump, and in the valley to the right (west) is the ancient bala'at of Akhdar. Here, also, there is no village, though close to the fort were a few black tents of sume wandering Bedouins. Akhdar had been mentioned as a possible site for the future lazaret. There is a fairly large flat surface here, surrounded on all sides by hills. But the site would be in many ways inferior to that at Tebuk. We did not measure it, but it is certain that it would barely suffice (if, indeed, it did suffice) to contain all the cordons and buildings that it is proposed to put up in the first instance, and would not allow of expansion in the future, should such prove necessary. Moreover, being shut in by hills, there would be a lack of free circulation of air and the heat would be great.

Here, as in many other parts of the line, there is quite a considerable amount of desert herbage to break the monotony of unending sand and stones. In the Akhdar neighbourhood the colocynth plant is found in large quantities, creeping like a low-growing vine along the ground, and shedding its mottled gourds in all directions. Here also are found any number of annuloid fossils, to which the Bedouins give the unsavoury name of "Job's worms"; believing, it would seem, that it was in this desert that Job was finally cleansed and purged of his bodily ills. The water at Akhdar is said to be abundant and it proved to be of better quality than any other examined by the Commission. The specimen analysed was taken from the well in the kala'at and gave the following results. The water was colourless and clear and without smell ; it contained 2.6 parts of chlorine as chlorides ; 0.148 total nitrogen, of which 0.139 occurred as nitrates, 0.003 as free ammonia, and 0.006 as organic nitrogen ; the oxygen consumed in the permanganate process in three hours at $27^{\circ} \mathrm{C}$. was 0.0955 ; the total hardness was 14.21, and the permanent hardness after boiling $5 \cdot 29$. The total solids were 37 . As before, all these figures represent parts per 100,000 .

After a brief stay at Akhdar the Commission went on to Medaini-Salih, a night's journey further down the line. The approach to Medaini-Salih is through a remarkable bit of scenery. The line winds down through a gorge in the sandstone mountains, known to the Arabs as the Mubrakat-elNaka, or the valley of the "Camel-calf." The mountains in this portion of Arabia-not merely in the gorge-have been split up into the most fantastic forms: pinnacles, towers, and shapelessly monstrous objects of every kind rise abruptly from the sand, and it is really small wonder that the pilgrims have peopled this weird passage with evil spirits, whom they try to frighten away by loud cries as they pass through the gorge on their way to Medina. At the end of the gorge, but still surrounded by groups of the weird rocks, is the place known as MedainiSalih-the "Cities of the Prophet Salih." The station is at the 955th kilometre from Damascus, and 347 north of Medina. It lies 820 metres above sea-level. There is no village of any kind here, and the only traces of the ancient "cities" are those wonderful Nabatæan monuments and inscriptions which must for ever be associated with the names of Doughty and Rénan. The old kala'at in which Mr. Doughty spent so many weary weeks still stands, with its reservoir by the side; but close by the railway has built its high water-tower and other of the station buildings almost surround the fort. The number and extent of these buildings show that this place is an important administrative centre on the line. They occupy the middle of a large, sandy plain dntted with tussocks of desert herbage, here more abundant

Nos. I. and II. were published in THE LANOET of Sept. c6th, p. 971, and Oct. 10th, 1908, p. 1104, respectively. 